\title{
A DEFINIÇÃO PRIVADA DO BEM PÚBLICO: a atuação de institutos empresariais na esfera da cultura ${ }^{1}$
}

\author{
Miqueli Michetti*
}

\begin{abstract}
O artigo analisa a atuação pública de institutos empresariais privados na esfera da cultura no Brasil contemporâneo. Tal atuação é condicionada pelo poder público nacional por meio de leis de incentivo à cultura via renúncia fiscal. O objetivo principal do texto é perscrutar como fundações e institutos privados se colocam como uma das mediações que permitem a conversão de capital econômico em poder político, ou, ainda, em governança pretensamente pós-política. A metodologia da pesquisa que embasa o artigo consistiu em revisão bibliográfica e em análise de dados qualitativos e quantitativos sobre o uso de recursos públicos oriundos de renúncia fiscal. A análise sociológica de discurso também embasou o estudo. Como conclusão, o artigo aponta para a reabertura do debate sobre a legitimidade de agentes privados que atuam publicamente, o que significa fazer uma indagação sobre o caráter mesmo da democracia.

Palavras-Chave: Institutos Culturais. Leis de Incentivo à Cultura. Brasil Contemporâneo. Pós-Política. Legitimidade.
\end{abstract}

\section{APRESENTAÇÃO: imbricações en- tre cultura, economia e política}

As lições da sociologia econômica e da antropologia do mercado nos ensinam que a esfera econômica não é independente da esfera da cultura (Bourdieu, 2000; Jameson, 2004; La Pradelle, 1996; Steiner, 1994). Se Karl Polanyi (1980) já apontava que sistemas econômicos se ancoram em relações sociais, David Harvey (1992) indica que a cada regime de acumulação corresponde um modo de regulamentação social, político e cultural. Economia, política e cultura existem em complexa relação de interdependência, que só pode ser negligenciada por meio do recurso ao que Bourdieu (1998, 2000) chama de "ficção economicista". É importante ressaltar, no entanto, que as relações entre o universo econômico e o reino cultural não são

* Fundação Getulio Vargas (FGV). Escola de Administração de Empresas de São Paulo (EAESP)

Rua Itapeva, 474, $7^{\circ}$ andar. Cep: 01332-000. Bela Vista São Paulo - Brasil. miquelimichetti@gmail.com

${ }^{1} \mathrm{O}$ presente artigo é resultado de uma pesquisa apoiada pelo GV Pesquisa, que concedeu à autora bolsa de apoio à pesquisa no Brasil, e pela FAPESP, que outorgou à autora a bolsa que custeou a realizacão de um pós-doutorado realizado no Institute of Latin American Studies da Columbia University. Agradeço às três instituições pelo apoio. imediatas nem diretamente causais. Além disso, elas não formam um sistema sem lacunas no qual a cultura e economia se equacionariam, mas expressam e produzem contradições.

No atual momento histórico, o ápice da acumulação de capital radica no setor financeiro (Harvey, 2008; Sassen, 2015). As implicações culturais dessa conjuntura marcada por uma economia financeirizada e com altos níveis de concentração são muitas e, no presente artigo, um fenômeno específico desse universo será analisado. Trata-se das maneiras pelas quais grandes bancos privados têm influído na esfera da cultura no Brasil, especialmente por meio de seus braços sem fins lucrativos.

Uma precisão a ser feita antes de continuarmos se reporta ao conceito de cultura. Conceito polissêmico, ele pode designar tanto um modo de vida no sentido mais amplo quanto a esfera da arte em seu significado mais restrito (Eagleton, 2005), bem como fenômenos ou processos que consideramos como de "média escala", por serem menos amplos do que a primeira definição e mais amplos que a segunda. Quando construídos como objetos sociológicos, tais processos de média escala nos 
permitem apreender aspectos específicos de determinada configuração social, mas podem informar, também, sobre dinâmicas e relações mais amplas neles implicadas. No caso particular deste artigo, ao analisarmos a atuação de fundações e institutos empresariais na esfera da cultura, podemos apreender elementos pontuais de tal atuação, algo relevante em si, mas também vislumbrar, a partir do universo cultural, as relações mais gerais estabelecidas entre empresas, instituições sem fins lucrativos e Estado no Brasil contemporâneo.

Em grande medida, a atuação cultural de grupos empresariais do setor financeiro é condicionada pelo poder público nacional, por meio de leis de incentivo à cultura via renúncia fiscal, e, frequentemente, se faz mediada por fundações e associações civis privadas sem fins lucrativos, ligadas a tais grupos, chamadas geralmente de "institutos". Esses três agentes - grupos corporativos do setor financeiro, poder público e organizações sem fins lucrativos - farão parte do escopo deste artigo, cujo foco principal incide sobre a atuação pública de institutos empresariais privados. Em termos mais gerais, as linhas a seguir investigam algumas das mediações que permitem que a concentração de capital econômico se transforme em poder político, ou, ainda, em atuação pretensamente pós-política, noção que exploraremos no decorrer do texto.

A metodologia da pesquisa qualitativa que embasa este artigo consistiu em revisão bibliográfica, análise de dados qualitativos e quantitativos sobre o uso de recursos públicos via mecanismos de renúncia fiscal por empresas privadas com e sem fins lucrativos, bem como em realização de algumas entrevistas. A análise sociológica de discurso embasou o estudo dos casos escolhidos para investigação. Tomamos como corpus os dois maiores grupos de empresas de serviços financeiros do país, Bradesco e Itaú, e suas respectivas formas de atuação na área da cultura por meio de leis de incentivo, e buscamos compará-las ressaltando o que elas têm em comum e também o que as diferencia. A diferença principal radica no fato de que um deles patrocina eventos esparsos, realizados por outras empresas e organizações, enquanto o outro atua publicamente na área da cultura de maneira mais sistemática, por meio de uma instituição sem fins lucrativos.

O artigo aborda, a seguir, a questão da legitimação, a partir da hipótese de que essa é uma das razões cruciais pelas quais empresas do setor financeiro se voltam à área da cultura. Na sequência, são discutidas algumas relações entre poder público e capital privado no que tange às políticas públicas de incentivo à cultura via renúncia fiscal para chegarmos, então, ao ponto crucial do artigo: a atuação pública de institutos empresariais privados na área da cultura. Como fechamento do artigo, são estabelecidas algumas reflexões teóricas e considerações finais.

\section{SÍSIFO E A LEGITIMAÇÃo}

A ligação da arte com o poder, seja ele religioso, político ou econômico, é secular (Gombrich, 2012). As análises das implicações sociais das relações entre cultura - agora no sentido amplo Eagleton - e poder político-econômico têm vários matizes. A ideologia em Marx e Engels (2001), a legitimidade em Weber (1996, 2012), a hegemonia em Gramsci (1991) e o poder simbólico em Bourdieu (1989) são alguns dos capítulos mais marcantes sobre as maneiras pelas quais as relações entre cultura e poder foram compreendidas em diversas vertentes das Ciências Sociais. Não alcançaremos as muitas nuances dessas variadas análises na extensão deste artigo, mas é importante ressaltar a complexidade que marca as conexões entre cultura e poder, uma vez que nos debruçaremos, a seguir, sobre algumas das formas pelas quais tais conexões são atualizadas no presente.

De crucial importância para nossos argumentos centrais é a questão da legitimidade. Por que o poder se interessa pela cultura? 
Porque a dominação só se sustenta se for legítima (Weber, 1996), já que o fundamento de qualquer tipo de dominação radica na crença em sua legitimidade (Weber, 2012). No limite, também porque "Onde existe poder, existe resistência" (Foucault, 1985, p. 91), ou seja, porque a legitimidade nunca é algo dado. Ao discutir especificamente a legitimidade de fundações filantrópicas, Steven Heydemann e Stefan Toepler (2007) apontam que nenhuma resolução da questão da legitimidade é permanente, universal ou totalmente segura. Pode-se dizer que a manutenção da legitimidade é um trabalho de Sísifo. Em configurações sociais nas quais existem altas concentrações de capital político e econômico, o esforço dessa manutenção tende a ser tanto mais interminável. E em sociedades que se pretendem democráticas, a infindável tarefa de despertar e manter a legitimidade do poder passaria por "travestir a defesa dos próprios interesses particulares como se estes representassem a virtude universal" (Souza et al., 2009, p. 87).

Em meados do século XX, quando as grandes corporações de capital monopolista se inseriam - de forma contraditória, mas efetiva - em uma espécie de "pacto" com o Estado keynesiano e com o trabalho sindicalmente organizado (Harvey, 1992), a legitimidade das empresas passava pelo desempenho de alguns papéis, que, especialmente no que se refere aos Estados Unidos e a outras "economias avançadas", consistiam em contribuir para a estabilidade econômica, para o pleno emprego, para o aumento do padrão de vida e para o renome internacional das respectivas indústrias nacionais. Na chamada sociedade salarial (Castel, 1998), a grande empresa pretende exercer uma espécie de "papel civilizacional" ligado a "projetos nacionais" e ao estratégico posicionamento internacional em uma conjuntura geopolítica marcada pela Guerra Fria. A imensa concentração de poder econômico e político se justificava socialmente na medida em que o grande capital somava esforços na disputa pela hegemonia em um mundo dividido.
A década de 1970 assiste à crise do fordismo-keynesiano e ao início do desmonte da sociedade salarial. Teríamos entrado, então, em um regime de acumulação flexível, o que implicaria uma economia globalizada em termos de mão de obra, da produção e consumo de bens e serviços e do mercado de dinheiro e crédito. Tratar-se-ia de outro regime de acumulação que implicaria outro modo de regulamentação. No contexto do aumento da desigualdade inerente a nesse novo regime, a esfera econômica buscará formas de legitimar a existência simultânea de riqueza e miséria, de necessitados e filantropos. Ao mesmo tempo, a filantropia se recolocará a tarefa de se ocupar dos perdedores da luta darwinista pelo sucesso na economia de mercado.

É esse contexto que dá origem a fenômenos como a venture philanthropy e o philanthropocapitalism (Bishop; Green, 2008; Wilson, 2014). A mesma conjuntura assiste à gestação da ideia de "responsabilidade social corporativa". Como boa parte das consequências da concentração de capital privado são públicas, comuns, a partir da década de 1990, o mundo da empresa não poderá eximir-se de medidas sociais compensatórias. Não demorou que isso fosse transformado no chamado "investimento social privado” (Nogueira; Schommer, 2009), ou seja, que a responsabilidade legal de compensação social fosse transmutada na concepção de investimento da empresa na sociedade.

A esfera da cultura, especialmente em sua dimensão artístico-estética, será uma das áreas sobre a qual as empresas buscarão atuar ou "investir socialmente". Por ter sido construída na história como o oposto das necessidades imediatas da vida material e dos interesses econômicos (Bourdieu, 1996; Gombrich, 2012; Michetti, no prelo; Warnke, 2001), a cultura tem sido um domínio privilegiado ao qual se recorre na tentativa de transformar discursivamente interesses particulares em virtudes gerais. Patrocinar a cultura costuma ser uma das vias da legitimação do capital econômico. Além disso, em tempos de responsabilidade 
social corporativa, uma empresa que "investe" em cultura pode ter um diferencial em termos de imagem. A noção de "marketing cultural" é contemporânea dessas discussões (Augustin, s/d; Ponte, 2012, Reis, 2003).

Entretanto, em países cujas economias não são "avançadas", a dimensão da cultura não é um alvo imediatamente legítimo de investimento, pois a sociedade tende a identificar outras prioridades. Não sendo considerada inerentemente legítima, a esfera da cultura percorrerá dois "atalhos" em busca de legitimidade, processo que não é exclusivo a países "em desenvolvimento". Um deles é utilitário e se refere ao potencial econômico da cultura, no momento em que mundialmente se estatui que a "economia criativa", que tem a cultura como ativo principal, seria um dos caminhos que levaria ao desenvolvimento econômico. O outro passa pela dimensão dos direitos, mais especificamente pelos chamados direitos culturais e, convergentemente, pela "proteção e promoção da diversidade das expressões culturais". No primeiro caso, a cultura seria algo "bom pra todos" por implicar diretamente desenvolvimento econômico, mantra último do mundo contemporâneo. No segundo, ela seria imediatamente positiva para as chamadas minorias, mas, quando a diversidade passa a ser concebida como valor universal (Ortiz, 2007; 2015) e como recurso humano valioso (Michetti, no prelo), ela seria estendida também à "sociedade como um todo". Assim, ainda que marginal, se "patrocínio" à cultura pode ser uma boa opção àqueles que têm por objetivo transfigurar inte$\dot{\infty}$ resses particulares em conveniência geral.

\section{LEIS DE INCENTIVO À CULTURA E} GRUPOS EMPRESARIAIS DO SETOR FINANCEIRO

Em vigor no Brasil desde os anos 1990, as leis de incentivo à cultura via renúncia fiscal têm sido o principal veículo de incentivo à cultura no país. Ensaiada logo após a redemocratização, a primeira lei de incentivo foi a Lei Sarney (Lei Federal $n^{0}$ 7.505), que, sob Collor, seria extinta e logo em seguida reformada e expandida como Lei Rouanet (Lei Federal $\mathrm{n}^{\circ}$ 8.313/1991). Ainda em vigor, o Programa Nacional de Incentivo à Cultura seria composto pelo Fundo de Investimento Cultural e Artístico (Ficart), pelo Fundo Nacional da Cultura (FNC) e ainda pelo incentivo a projetos culturais, conhecido como mecenato. Os percentuais de renúncia variaram, mas, atualmente, pessoas físicas podem abater $6 \%$ de seu imposto de renda devido para doações a projetos culturais; para pessoas jurídicas, essa importância é de $4 \%{ }^{2}$ Com isso, as empresas maiores e mais lucrativas, que, em termos absolutos, devem mais impostos aos cofres públicos, são as que dispõem de mais recursos para "investir" em cultura, de forma que ao acúmulo de capital econômico corresponde uma maior monta de influência no que ocorre culturalmente no país. ${ }^{3}$

Embora tenha especificidades, o modelo adotado pelo Brasil não é inédito no mundo. Ao contrário, a partir dos anos 1980, os mecanismos de incentivo fiscal a doações privadas à cultura são instituídos ou intensificados em países como Inglaterra e EUA (Wu, 2006). Eles se baseiam em uma premissa que assume que a empresa privada é o agente mais apropriado para gerir o mundo social, que, em última instância, se reduziria ao mundo econômico. Com as leis de renúncia fiscal, as empresas, ao assumirem o protagonismo na distribuição dos recursos públicos, atenderiam, de maneira mais eficiente, aos interesses de toda a sociedade. $\mathrm{Na}$ visão de mundo neoliberal, que é ao mesmo tempo uma doutrina econômica e um projeto político (Bourdieu, 1998), o Estado passa

\footnotetext{
${ }^{2}$ http://www.planalto.gov.br/ccivil 03/Leis/L9532.htm. A lei está disponível na íntegra em http://www.planalto.gov.br/ ccivil_03/LEIS/L8313cons.htm\#art3. Acesso em: 20/10/2015.

${ }^{3}$ Até o momento de redação deste artigo, a Lei Rouanet permitia a dedução de imposto apenas às empresas que declaram "lucro real", portanto grandes empresas, o que estava em discussão na Câmara e no Senado. Ver http://www2.camara.leg. br/camaranoticias/noticias/EDUCACAO-E-CULTURA/495927COMISSAO-APROVA-LUCRO-PRESUMIDO-PARA-DEDUCAO-POR -LEI-ROUANET.html. Acesso em: 15/11/2015.
} 
a ser concebido como um intermediário e um garantidor da ordem das coisas, e tudo mais é tocado adiante pela esfera corporativa. Em nenhum lugar do mundo, entretanto, o projeto neoliberal passou ao largo da ação do Estado (Harvey, 2008; Sassen, 2007). Ao contrário, ele é um dos agentes da implementação de tal projeto em áreas tão distintas quanto gestão da água e fomento à cultura. Uma relação privilegiada com o poder estatal é crucial para se garantir sucesso no mundo do livre mercado (Harvey, 2008).

No que tange a nosso assunto, o fenômeno de incentivo estatal ao protagonismo de empresas privadas na alocação de recursos públicos se evidencia quando consideramos que o orçamento total do Ministério da Cultura para 2014 foi de $\mathrm{R} \$ 3,26$ bilhões, ${ }^{4}$ montante dividido entre as despesas de manutenção da instituição e "ações finalísticas", ou seja, apoio a projetos culturais, ao passo que o total da captação de recursos via Lei Rouanet foi de mais de R 1.33 bilhões, isso sem contar os recursos captados também via renúncia de receita, por meio da Lei do Audiovisual (Lei Federal 8.685/93). Com isso, podemos começar a ter uma ideia sobre a dimensão da influência que esse modelo de incentivo às "doações" privadas exerce no financiamento à cultura no país.

Na Tabela 1, temos mais elementos para perceber a proporção de despesas públicas e de investimento privado nos termos do "mecenato" da Lei Rouanet. Observe-se que, quando a lei entrou em vigor, a porcentagem de renúncia fiscal (B) no montante captado (A) era de $30 \%$, enquanto o apoio privado (C) respondia por $70 \%$ dos recursos. Com a pressão exercida por grupos de interesse, especialmente após a

Tabela 1 - Lei Rouanet - Mecenato. Captação de recursos, renúncia e apoio privado (em $R$ \$)

\begin{tabular}{|c|c|c|c|c|c|}
\hline Ano & Captação (A) & Renúncia (B) & $\%(B / A)$ & Privado (C) & $\%(\mathrm{C} / \mathrm{A})$ \\
\hline 1993 & $21.212,78$ & $6.363,83$ & 30,00 & $14.848,95$ & 70,00 \\
\hline 1994 & $533.751,57$ & $166.531,47$ & 31,20 & $367.220,10$ & 68,79 \\
\hline 1995 & $12.913 .764,52$ & $4.344 .258,73$ & 33,64 & $8.569 .505,79$ & 66,35 \\
\hline 1996 & $111.703 .236,39$ & $36.825 .531,24$ & 32,96 & $74.877 .705,15$ & 67,03 \\
\hline 1997 & $207.949 .307,41$ & $68.350 .337,22$ & 32,86 & $139.598 .970,20$ & 67,13 \\
\hline 1998 & $232.573 .368,83$ & $95.405 .041,78$ & 41,02 & $137.168 .327,05$ & 58,97 \\
\hline 1999 & $211.370 .509,24$ & $111.244 .685,68$ & 52,63 & $100.125 .823,56$ & 47,36 \\
\hline 2000 & $290.013 .845,79$ & $186.454 .528,51$ & 64,29 & $103.559 .317,29$ & 35,70 \\
\hline 2001 & $368.126 .066,04$ & $236.153 .700,18$ & 64,15 & $131.972 .365,86$ & 35,84 \\
\hline 2002 & $344.613 .923,65$ & $263.308 .924,95$ & 76,40 & $81.304 .998,70$ & 23,59 \\
\hline 2003 & $430.893 .947,10$ & $359.229 .929,38$ & 83,36 & $71.664 .017,72$ & 16,63 \\
\hline 2004 & $511.763 .571,72$ & $442.947 .429,81$ & 86,55 & 68.816.141,91 & 13,44 \\
\hline 2005 & $726.735 .180,39$ & $635.975 .173,58$ & 87,51 & $90.760 .006,81$ & 12,48 \\
\hline 2006 & $854.467 .419,48$ & $762.364 .775,02$ & 89,22 & $92.102 .644,46$ & 10,77 \\
\hline 2007 & $990.167 .302,71$ & $884.338 .482,35$ & 89,31 & $105.828 .820,36$ & 10,68 \\
\hline 2008 & $963.736 .956,53$ & $878.313 .868,19$ & 91,13 & $85.423 .088,34$ & 8,86 \\
\hline 2009 & $980.035 .962,32$ & $894.377 .342,15$ & 91,25 & $85.658 .620,18$ & 8,74 \\
\hline 2010 & $1.166 .378 .054,32$ & $1.063 .711 .800,32$ & 91,19 & $102.666 .254,00$ & 8,80 \\
\hline 2011 & $1.324 .357 .027,23$ & $1.225 .218 .649,03$ & 92,51 & $99.138 .378,20$ & 7,48 \\
\hline 2012 & $1.276 .832 .533,20$ & $1.194 .955 .818,04$ & 93,58 & $81.876 .715,16$ & 6,41 \\
\hline 2013 & $1.261 .717 .017,10$ & 1.195.588.866,05 & 94,75 & $66.128 .151,05$ & 5,24 \\
\hline 2014 & $1.334 .514 .238,94$ & $1.260 .990 .438,92$ & 94,49 & $73.523 .800,02$ & 5,50 \\
\hline 2015 & $565.588 .349,14$ & $529.800 .302,18$ & 93,67 & $35.788 .046,97$ & 6.32 \\
\hline
\end{tabular}

Fonte: SalicNet/MinC

4 Disponível em: http://oglobo.globo.com/cultura/orcamento-cultura-fica-com-326-bilhoes-em-2014-240-milhoes-menos-que-2013-11105216. Acesso em: 14/09/2015.

implementação da Lei do Audiovisual, que permitia que o abatimento fosse de até 100\% sobre 
4\% do imposto devido, concedendo ainda que o valor fosse lançado como despesa nas folhas da empresa, o percentual foi se invertendo também na Lei Rouanet. Atualmente, a renúncia fiscal, ou seja, o dinheiro público, corresponde a $93,5 \%$ do total de recursos captados, de forma que o apoio privado é de cerca de 6,5\%.

Estando claros tanto o protagonismo dos recursos públicos quanto a posição coadjuvante do Estado, passemos agora aos protagonistas que analisamos neste artigo. De acordo com dados da Forbes, ${ }^{5}$ a lista das maiores empresas brasileiras, em 2015, seria assim composta em suas primeiras posições: 1) Itaú Unibanco Holding; 2) Banco Bradesco; 3) Banco do Brasil; 4) Vale e 5) Petrobras. A posição das empresas públicas se alterou em 2014 e 2015 em razão das crises política e econômica atravessadas pelo país. No entanto, os últimos dados divulgados pelo Banco Central confirmam que os dois maiores bancos privados do país são o Itaú e o Bradesco. ${ }^{6}$ Para os propósitos deste artigo, o importante é ressaltar que os dados disponibilizados pelo SalicNet ${ }^{7}$ permitem observar uma relação direta entre concentração de capi๑ tal e influência na distribui¿्๋ ção dos recursos públicos હ્ષ para a área da cultura.

这 Os dados são de 2015

मे por serem os mais recentes

consolidados no momen-

to de redação deste artigo.

$\stackrel{\infty}{\infty}$ Eles revelam, entretanto,

¿ uma tendência que se re-

จิ pete ano após ano: as maio-

res empresas do país são

as que mais patrocinam a
Tabela 2 - 20 Maiores Incentivadores - Modalidade Mecenato. 2015

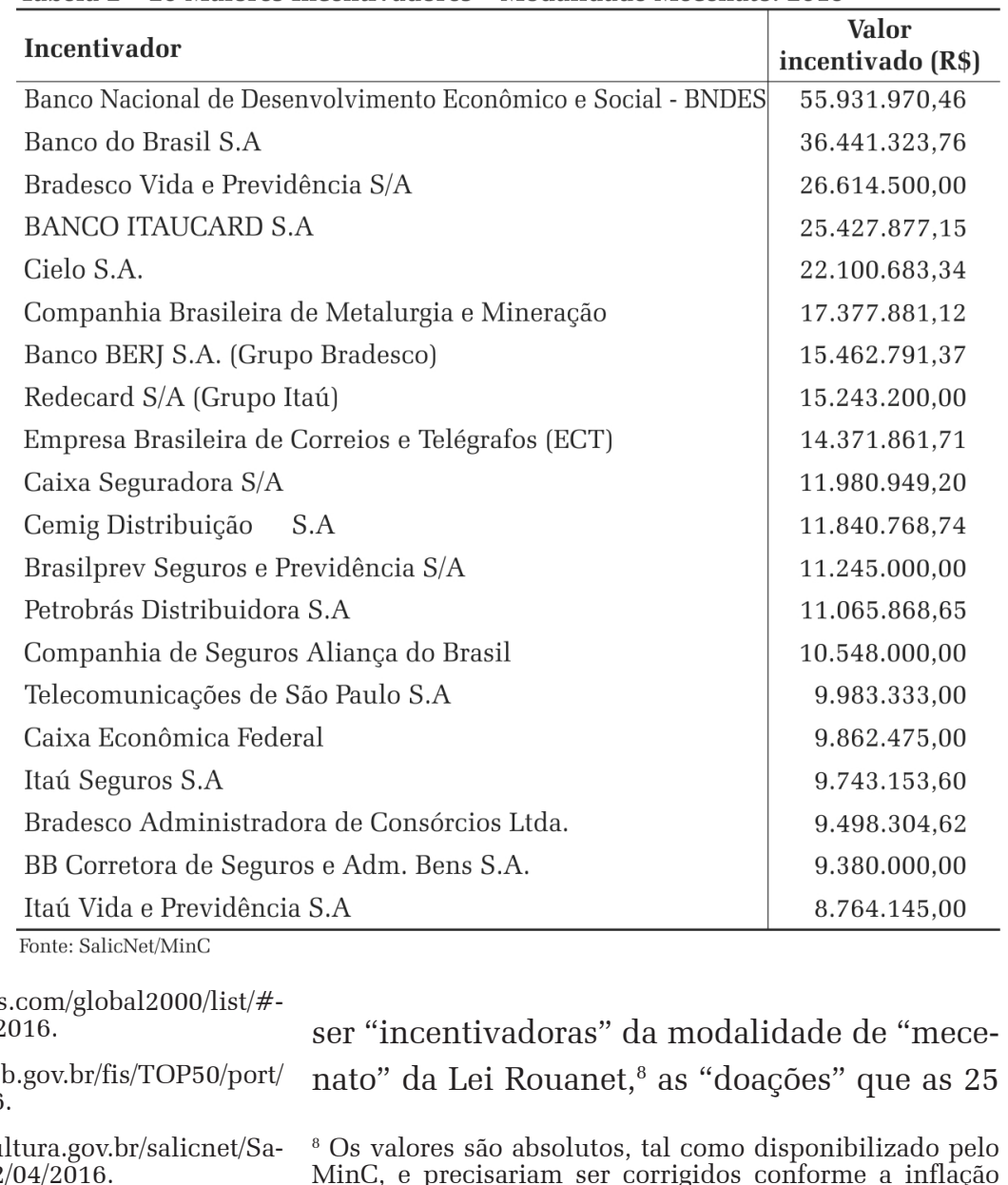


diferentes pessoas jurídicas (CNPJs) ligadas ao Grupo Bradesco já fizeram a projetos culturais via mecenato ou Lei Rouanet, até 2014, foi de R \$ 582,7 milhões. O montante de renúncia fiscal de que as 53 empresas do Grupo Itaú já se beneficiaram pelo mesmo mecanismo somam juntas R \$ 628,9 milhões até 2014.

Os números são sintomáticos, mas eles não falam por si mesmos. Logo, cabe perguntar como se dá esse "mecenato" e que tipo de projetos culturais ele patrocina. Tomemos, inicialmente, o caso do Bradesco para buscar elementos de resposta a essa questão. ${ }^{9}$ Selecionamos os cinco maiores "incentivadores" entre os 25 CNPJs do grupo que se utilizam do mecanismo de renúncia fiscal. O montante de renúncia concedido aos 5 maiores soma $\mathrm{R} \$ 411.2$ milhões e, desde os anos 2000, eles já "incentivaram" 738 projetos culturais. Os projetos são variados e vão de reformas de patrimônio histórico ao apoio ao Réveillon de Copacabana e a blocos de carnaval, de concertos de natal nas sedes das empresas do grupo ao patrocínio de museus como MASP e MAM, da Festa da Uva de Caxias do Sul a temporadas da Orquestra Sinfônica Brasileira, sem contar os muitos musicais apresentados originalmente na Broadway, como $O$ Rei Leão, Shrek, O Mágico de $\mathrm{Oz}, \mathrm{A}$ família Adams e Mamma Mia... A lista é longa e crescente. Como se trata de um grupo empresarial que tem braços que operam no varejo, a opinião pública de Fonte: SalicNet/MinC

correspondente ao período para estarem propriamente atualizados.

9 A atuação mais sistemática do Grupo Bradesco se faz por meio da Fundação Bradesco na área de educação. Para mais informações, consultar http://www.fb.org.br/.

clientes atuais e potenciais é importante. Além disso, o valor de marca, de forma mais geral, também importa, pois o mais interessante é ter o nome da empresa associada a produções célebres, com público amplo e conteúdo isento de muitas polêmicas. Ressalte-se ainda o fato de que o banco pode reservar convites para clientes considerados especiais e, ainda, assumir porcentagem do lucro das produções.

O uso de incentivo fiscal como marketing cultural já foi objeto de trabalhos anteriores (Augustin, s/d; Olivieri, 2004; Reis, 2003; Rubim, 2007; 2013; Sarkovas, 2005) e esses exemplos nos bastam. No entanto, antes de passarmos ao nosso próximo caso, com o qual o anterior será comparado, é pertinente destacar o caráter das empresas que organizam boa parte desses musicais custeados com recursos Tabela 3 - Maiores proponentes de projetos de Mecenato - 2014

\begin{tabular}{|c|c|}
\hline Proponente & Valor captado (R\$) \\
\hline Aventura Entretenimento Ltda. & $21.712 .526,10$ \\
\hline Instituto Tomie Ohtake & $19.733 .528,17$ \\
\hline Museu de Arte de São Paulo Assis Chateaubriand & $17.824 .344,00$ \\
\hline Instituto Itaú Cultural & $14.730 .000,00$ \\
\hline T4F Entretenimento S.A. & $13.465 .000,00$ \\
\hline Fundação Bienal de São Paulo & $13.270 .450,00$ \\
\hline EXPOMUS - Exposições Museus Projetos Culturais Ltda. & $12.286 .000,00$ \\
\hline Fundação Orquestra Sinfônica Brasileira & $10.799 .780,80$ \\
\hline D+3 Produções Artísticas Ltda & 10.719.440,00 \\
\hline Instituto Cultural Inhotim & $10.592 .266,65$ \\
\hline Fundação Orquestra Sinfônica do Estado de São Paulo & $9.769 .386,18$ \\
\hline Museu de Arte Moderna de São Paulo-MAM & $8.076 .529,76$ \\
\hline Fundação Roberto Marinho & $7.550 .000,00$ \\
\hline Instituto Odeon & $7.460 .000,00$ \\
\hline Magnetoscópio Produções Ltda & 7.383.000,00 \\
\hline Campo da Produção, Eventos e Promoções Ltda. & 7.354.485,97 \\
\hline Só de Sapato Produções e Promoções Artística Ltda-ME & $7.067 .163,48$ \\
\hline SR Promoções Culturais Ltda & $7.000 .000,00$ \\
\hline Instituto Brasileiro de Gestão Cultural-IBGC & $6.962 .520,00$ \\
\hline Adriana Mentz Martins & $6.894 .000,00$ \\
\hline \multicolumn{2}{|l|}{ Fonte: SalicNet/MinC } \\
\hline
\end{tabular}


Empresas privadas de organização de eventos, como Aventura Entretenimento Ltda. e T4F Entretenimento S.A, operam com fins lucrativos. Os números são referentes a 2015, mas, somados todos os anos do mecanismo público de incentivo, verifica-se que a primeira já "captou" mais de R\$ 104 milhões junto ao MinC, e a segunda, se somarmos seus dois CNPJs inscritos como proponentes, arrecadou cerca de R 133 milhões.

Jogar luzes sobre esses agentes envolvidos na distribuição de recursos públicos para a área da cultura é fundamental, tanto mais que, em fevereiro de 2016, durante a pesquisa que deu origem a este artigo, o Tribunal de Contas da União (TCU) determinou a proibição de captação de recursos via Lei Rouanet de projetos com "potencial lucrativo", ou que "possam atrair investimentos privados". A mudança é oriunda de investigação que começou em 2011, após denúncia do Ministério Público, que entende que repasses a projetos lucrativos não atendem ao "interesse público", em dissonância com o previsto pela letra da Lei Rouanet. Até a finalização do artigo, não havia, contudo, previsão de quando a proibição entraria em vigor, inclusive porque o Ministério da Cultura teria afirmado, diante da determinação do TCU, não contar com uma classifi• cação a respeito de projetos que poderiam ser

10 Para mais informações, consultar: http://www1.folha. uol.com.br/ilustrada/2016/02/1736700-tcu-proibe-lei-rouanet-para-projetos-com-fins-lucrativos-e-autossustenస్ taveis.shtml; http://www.cultura.gov.br/noticias-desta- ques/-/asset publisher/OiKX3xlR9iTn/content/id/1319655

e ainda http://oglobo.globo.com/cultura/juca-ferreira-abre-

fogo-contra-lei-rouanet-15258675. Mais especificamente

sobre alguns dos interesses em disputa, consultar: http:// entretenimento.uol.com.br/noticias/redacao/2016/02/25/ sem-lei-rouanet-industria-dos-musicais-morre-diz-presidente-da-t4f.htm e http://entretenimento.uol.com.br/noti- substanciais no sistema de incentivo à cultura. A proibição parece resultar também de mobilizações sociais contrárias ao uso da lei em projetos altamente lucrativos. ${ }^{11}$

As acirradas disputas em torno do futuro do incentivo à cultura no país estão em andamento e devem ser tomadas como objeto de análise com o devido rigor pela sociologia da cultura, bem como por áreas afins. Por ora, voltemos ao cerne de nossa argumentação e percebamos, na tabela acima que, além de empresas privadas, institutos e fundações têm lugar de destaque como principais proponentes de projetos ao atual formato de mecenato da Lei Rouanet. A tais instituições nos dedicaremos a seguir.

\section{A ATUAÇÃO DE INSTITUTOS EM- PRESARIAIS PRIVADOS NA ESFE- RA DA CULTURA}

Mais da metade das entidades privadas sem fins lucrativos existentes no Brasil em 2010 eram Fundações Privadas e Associações sem Fins Lucrativos (FASFIL). Em números absolutos, isso corresponde a $290,7 \mathrm{mil}$ de 558,6 mil. Em termos relativos, estamos falando de $52,2 \%$. Elas são definidas pelo IBGE como sendo a) privadas, b) sem fins lucrativos, c) institucionalizadas, d) autoadministradas ou capazes de gerenciar suas próprias atividades, e e) voluntárias, na medida em que podem ser constituídas livremente por qualquer grupo de pessoas (IBGE, 2012). No Brasil, há três figuras jurídicas que se enquadram nesses critérios, de acordo com o novo Código Civil: associações, fundações e organizações religiosas. As associações são constituídas pela união de pessoas que se organizam para fins não econômicos, e as fundações são criadas por um instituidor,

cias/redacao/2016/02/16/gigante-dos-musicais-produtoradiz-que-nao-sobrevive-sem-lei-rouanet.htm.

${ }^{11}$ Eis um exemplo: http://entretenimento.uol.com.br/noticias/redacao/2016/02/18/apos-repercussao-claudia-leittedesiste-de-publicar-livro-via-lei-rouanet.htm. Acesso em: 05/04/2016. 
mediante escritura pública ou testamento, a partir de uma dotação especial de bens livres, especificando o fim a que se destina. Diferentemente das associações, as fundações não têm membros, ela tem ou são um patrimônio e ficam sob a tutela do Ministério Público (Nogueira; Schommer, 2009).

O IBGE indica ainda que $87,3 \%$ das 290.692 FASFIL existentes no Brasil em 2010 foram criadas nos últimos 30 anos e 40,8\% nasceram apenas na década de 2000. Do total, 11.995 seriam do setor de Cultura e Arte, das quais 3.409 surgiram de 1991 a 2000 e 5.636 nasceram entre 2001 a 2010. De acordo com o censo realizado bienalmente desde 2001 pelo Grupo de Institutos, Fundações e Empresas, instituição que congrega as principais, maiores e mais atuantes fundações e institutos empresariais no país, $83 \%$ deles têm até 30 anos de existência e 47\% foram criados nos últimos 10 anos (GIFE, 2013). A publicação define Institutos e Fundações Empresariais (FIEs) como "organizações sem fins lucrativos, criadas e mantidas por uma empresa ou seus acionistas. São geridas por pessoas ligadas à empresa que as mantém”.

Embora pareça paradoxal, os números atinentes aos institutos e fundações privados dão notícias da existência de incentivo público-estatal à arte e à cultura. Mas eles apontam também para as maneiras específicas pelas quais tais incentivos se dão na conjuntura neoliberal. Em boa medida, eles constituirão uma composição entre instituições sem fins lucrativos, empresas e Estado e serão parte de um fenômeno ou movimento mais geral de separação entre público e estatal. Esse processo ocorre globalmente. Alguns autores o descrevem como uma configuração "pós-democrática" caracterizada por "acordos entre partes interessadas" (stakeholders) em "arranjos de governança em que o Estado tradicional opera institucionalmente junto com especialistas, ONGs e outros parceiros responsáveis" (Swyngedouw, 2010).

Retomando criticamente autores da chamada teoria política pós-fundacional, Swyngedouw aponta que estaríamos vivendo uma “condição pós-política”, marcada pela predominância da lógica administrativa em todos os aspectos da vida, diagnóstico que coincide com os argumentos de Boltanski e Chiapello (1999), e ainda de Dardot e Laval (2010). Nela, o político seria reduzido ao administrativo e as tomadas de decisão públicas seriam concebidas como questão de conhecimento especializado, ao largo de questões políticas. Tal condição seria acompanhada pela difusão da governança entre uma série de atores institucionais não estatais ou semiestatais, e buscaria uma consensualização das políticas a partir de argumentos pretensamente técnicos.

No Brasil, esse processo começa a ganhar forma nos anos 1990. Elizabeth Ponte informa que, no bojo da chamada Reforma do Estado colocada em curso a partir de 1995, a lei das Organizações Sociais (OSs - Lei Federal $n^{0}$ 9.637/98) e a lei das Organizações da Sociedade Civil de Interesse Público (Oscips - Lei Federal no 9.790/99) teriam ensejado "o fortalecimento das ações de parceria entre o governo e o chamado Terceiro Setor, criando um "espaço público não estatal" e "um modelo de gestão pública conhecido como publicização, contratualização ou simplesmente gestão pública não estatal” (Ponte, 2012).

Essas transformações apontam para algo mais geral do que a área da cultura. É no momento em que as concepções neoliberais sobre o Estado passam a se disseminar no Brasil que fundações e institutos corporativos adquirem força histórica. É preciso reiterar que os processos de globalização e o neoliberalismo não implicam um ocaso do Estado ou sua completa subsunção. Antes, o Estado assume papéischave na própria realização da globalização neoliberal (Sassen, 2007). Mike Raco (2010) afirma tratar-se de uma diminuição do governo concomitante a uma expansão do Estado na forma de um "novo Estado contratual".

Além disso, como vários autores se preocupam em demonstrar, a agenda neoliberal se desenrola de maneiras específicas conforme as situações específicas (Hilgers, 2012; Peck, 
2010; Wacquant, 2012). No Brasil, saímos da ditadura em meados da década de 1980, quando o mundo já ensaiava o modelo neoliberal. Por aqui, a "superação do estatismo varguista" estaria na pauta dos primeiros governos pós -redemocratização (Sallum, 1999). A "Reforma do Estado" previa uma participação maior da chamada "sociedade civil" na condução dos rumos coletivos do país. ${ }^{12}$ Ao mesmo tempo em que intentava deixar para trás a herança ditatorial, tal reforma apontava para as transformações pelas quais vinham passando os Estados-nação para acomodar dinâmicas e processos globais. De um lado, a promessa democrática, de outro, a abertura para o aumento do poder do capital privado.

A Constituição de 1988 já manifestava essas tensões, que se colocam na mesma conjuntura em que, com a derrocada da experiência socialista, se criava, sob a bandeira da Terceira Via, um quase consenso mundial acerca da coincidência necessária entre capitalismo e democracia. A chegada do Partido dos Trabalhadores ao governo federal também se faz mediante um arranjo dessas tensões (Nobre, 2013; Singer, 2012). Sob Lula, a extrema pobreza no país era eliminada, ao mesmo tempo em que os bancos privados batiam recordes de lucratividade. Expressões como "neoliberalismo de es๑ querda", "neoliberalismo desenvolvimentista" e : ¿ conta dessas contradições no nível conceitual.

Essas complexas dinâmicas se inscrevem na esfera da cultura de várias maneiras, e o processo que temos analisado é uma delas. Quando Gilberto Gil assume o Ministério da Cultura sob Lula, por exemplo, muitos esperavam que a Lei Rouanet fosse revogada para dar lugar a mecanismos de incentivo menos concentradores. Não só ela continuou em vigor, como também as empresas estatais continuaram a utilizá-la de forma massiva. Outras iniciativas foram criadas

12 Sobre a Reforma do Estado, consultar Bresser Pereira, Luiz Carlos. A reforma do Estado dos anos 90: lógica e mecanismos de controle. Lua Nova n. 45, 1998. Sobre o termo sociedade civil, consultar Alves, Mario Aquino. O conceito de sociedade civil: em busca de uma repolitização. Organização e Sociedade. supostamente para compensar a conhecida e reconhecida concentração resultante de sua aplicação (Medeiros; Alves; Farah, 2015; Rubim, 2013), mas os interesses estabelecidos em torno dela não foram importunados (Rubin; Barbalho; Calabre, 2015).

Dentre as empresas privadas e públicas que lançam mão dos mecanismos de renúncia fiscal, algumas atuam apenas como incentivadoras, que é o termo usado pelo MinC para empresas que têm uma parte dos impostos devidos aplicados em variados projetos culturais de sua escolha. Outras empresas, como foi visto nos casos da Aventura Entretenimento e da T4F Entretenimento, são proponentes e apenas captam recursos. Alguns grupos, entretanto, cobrem as duas pontas do mecanismo de incentivo, ou seja, contam com empresas que entram como incentivadoras e têm institutos e fundações que são proponentes de projetos e captam recursos, fechando o circuito no qual o Estado aparece como intermediário. Vejamos como isso se dá em termos mais concretos.

\section{A atuação pública do Instituto Itaú Cultural}

Todas as grandes empresas do país, atualmente, realizam "investimento social privado" e boa parte delas tem fundações e institutos próprios para tanto, como é o caso dos dois maiores grupos privados do país, Itaú e Bradesco. Em cultura, as empresas do grupo Bradesco atuam apenas como incentivadores, já que sua fundação é voltada principalmente para a educação. Já ao grupo Itaú Unibanco ligam-se o Instituto Unibanco, o Instituto Moreira Salles (atualmente independente), a Fundação Itaú Social e o Instituto Itaú Cultural. Além disso, recentemente, membros das famílias ligadas ao grupo têm criado "institutos" e fundações familiares. ${ }^{13}$

O Instituto Itaú Cultural será tomado como exemplo heurístico do processo em aná-

${ }^{13}$ Bilionários com causa. Revista Exame. Edição 1092, Ano 49, n.12, 24/6/2015. 
lise. Ele ilustra bem o mecanismo por meio do qual instituições privadas, sem fins lucrativos, ligadas a grandes empresas, assumem a posição de planejar e decidir o destino de recursos públicos no país. Além disso, por ser ligado ao maior grupo financeiro nacional e por ter boa parte dos recursos oriundos de renúncia fiscal concedida pelo Estado às empresas do próprio grupo, o Itaú Cultural ocupou o $1^{\circ}$ lugar entre os proponentes de projetos culturais a serem custeados por recursos condicionados pela Lei Roaunet nos 5 dos 10 últimos anos. Em outros quatro desses 10 anos, ele ocupou o $2^{\circ}$ lugar e, em 2015, assumiu a $5^{\circ}$ posição, conforme observamos na Tabela 4. A instituição ocupa ainda o primeiro lugar entre os captadores denominados de Pessoa Jurídica Sem Fins Lucrativos, com captação de R 402.1 milhões de 1996 a 2015. Ademais, os Planos Anuais de Atividades do Instituto respondem a não menos que 5 dos 10 maiores projetos já apoiados por intermédio da modalidade mecenato.

Tabela 4 - 10 Maiores Projetos de Mecenato - MinC

\begin{tabular}{|c|c|c|c|}
\hline Ano & Projeto & Unidade & Valor captado \\
\hline 2010 & Museu da Imagem e do Som - MIS/RJ & RJ & $36.255 .500,30$ \\
\hline 2008 & $\begin{array}{l}\text { Theatro Municipal do Rio de Janeiro - } \\
\text { Restauração Interna }\end{array}$ & RJ & $35.684 .235,27$ \\
\hline 2008 & Plano Anual de Atividades 2009 & SP & $30.660 .000,00$ \\
\hline 2010 & $\begin{array}{l}\text { Plano Anual de Atividades } 2011 \text { - } \\
\text { Itaú Cultural }\end{array}$ & $\mathrm{SP}$ & $29.500 .000,00$ \\
\hline 2007 & Plano Anual de Atividades 2008 & SP & $29.500 .000,00$ \\
\hline 2008 & Restauro do Casarão do Valongo - Santos & SP & $28.577 .257,16$ \\
\hline 2000 & $\begin{array}{l}\text { Projeto de Restauração do Conjunto } \\
\text { Arquitetônico do Arquivo Nacional }\end{array}$ & RJ & $28.351 .000,00$ \\
\hline 2006 & Plano Anual de Atividades 2007 & SP & $27.000 .000,00$ \\
\hline 2009 & Plano Anual de Atividades 2010 & SP & $26.600 .000,00$ \\
\hline 2001 & Estação da Lingua Portuguesa & RJ & $25.527 .760,84$ \\
\hline
\end{tabular}

Fonte: SalicNet/MinC

Os valores nos dão uma ideia sobre a influência que a instituição tem exercido na área cultural no país. Mas, embora os números revelem bastante, eles não dizem tudo. A análise de outros elementos da atuação da instituição buscará, a partir de um objeto circunscrito, compreender mais acuradamente certas dinâmicas que têm marcado as atuais relações entre Esta- do, Mercado e "Terceiro Setor" no setor cultural brasileiro, especialmente no que diz respeito às vias pelas quais a concentração de capital econômico permite a atuação em âmbito público. Mais do que um objeto sob nossas lentes, o Itaú Cultural nos serve também como lupa para vislumbrarmos os processos em análise.

Fundado em 1987, o Instituto nasce com a redemocratização, dois anos depois do MinC e um ano após a primeira lei de incentivo à cultura via renúncia fiscal. Seu estatuto de criação informa que a associação civil "sem fins econômicos ou lucrativos" foi criada pelo "associado instituidor" Itaúsa - Investimentos Itaú S.A., tendo como "associados mantenedores" as "sociedades controladas pelo grupo empresarial”. A criação como associação não é gratuita. De acordo com legislação específica do Código Civil, as fundações são criadas por meio de dotações, que passam a ser formalmente públicas e podem ser transferidas caso a fundação seja extinta. Além disso, elas são "veladas" pelo Ministério Público (Nogueira; Schommer, 2009). Já as associações precisam de um instituidor e um mantenedor e são regidas pelos estatutos das próprias instituições. Apelidadas frequentemente de "institutos", possuem ligação direta com as empresas mantenedoras e contam com mais autonomia no que diz respeito ao poder público (Silva, 2000).

$\mathrm{Na}$ cerimônia de inauguração da unidade física da entidade, em 1989, o então presidente do Grupo Itaú, Olavo Egydio Setúbal, teria asseverado sua "certeza de que o presidente Sarney criou as condições para uma profícua e criativa interação entre o empresariado e o setor cultural, no momento histórico que a sociedade brasileira atravessa", ${ }^{14}$ manifestando ${ }^{14}$ Itaú Cultural. Legado. In: Relatório de atividades 2013. 
claramente que a "interação" entre "empresariado" e o "setor cultural" se dava a partir de condições criadas pelo poder público, ou seja, pelas leis de renúncia fiscal.

Embora esse procedimento seja difundido ao redor do mundo, a legitimidade sobre a qual repousa não é automática, que o digam as muitas críticas que a Lei Rouanet tem recebido desde que passou a operar. Nesse sentido, as instituições sem fins lucrativos que gozam de benefícios públicos de incentivo apresentamse como uma forma de mediar a atuação pública de agentes privados com capital econômico concentrado. Como as instituições sem fins lucrativos de maneira mais geral, o Instituto Itaú Cultural tem por objetivo atuar publicamente. Embora haja vínculos diretos entre os braços sem fins lucrativos dos grupos empresariais e suas empresas, a existência daqueles permite que grupos corporativos tenham uma atuação pública coordenada, sistemática e potencialmente mais legítima.

As instituições sem fins lucrativos precisam contar com legitimidade político-legal e social. Steven Heydemann e Stefan Toepler (2007) afirmam que a legitimidade das fundações seria calcada nas funções que elas assumem, como: a) redistribuir recursos; b) inovar além do que o Mercado e o Estado, por correrem mais riscos e estarem dispostas a fazer isso; e c) estabelecer ações afirmativas ou "discriminação positiva” com relação a grupos específicos de uma forma que o Estado, por ser universalista, não poderia. Já David C. Hammack (2007) afirma que a legitimidade das fundações nos EUA se baseia principalmente no fato de elas se da$\dot{s}$ rem a ver como uma parte do setor mais amplo das organizações sem fins lucrativos. Joan Roelofs (2003) evoca e contesta o argumento de que elas seriam legítimas por conferirem pluralismo às políticas públicas e contribuírem para a democracia. Helmut Anheier e Diane Leat (2013) também passam em revista e descartam todos os rationales acima. Kenneth Prewitt (2006) retoma os motivos geralmente elencados para justificar a legitimidade das fundações e os refuta para argumentar que, nos EUA, as fundações, antidemocráticas por definição, seriam legítimas em razão do que representam, pois sua presença seria uma afirmação simbólica do compromisso dos EUA com o liberalismo econômico. Para esse autor, a questão da legitimidade das fundações não é problematizada, porque elas seriam um emblema da busca central da sociedade liberal estadunidense de ligar riqueza privada e bem público, sem atentar contra a liberdade política e econômica.

Esses autores, dentre outros, destacam elementos relevantes para pensarmos a questão da legitimidade das instituições que temos analisado. No entanto, é preciso considerar que, no Brasil, a questão da legitimidade apresenta especificidades. Afinal, a posição que tais instituições assumem em cada sociedade liga-se às maneiras pelas quais diferentes grupos sociais concebem a esfera pública e os respectivos poderes do Estado, das forças de mercado e das outras instâncias sociais. Entre nós, o Estado assume uma posição mais central, como artífice social, ao passo que as instituições sem fins lucrativos historicamente assumem uma posição de menor destaque (Landim, 1993; 1998). Contudo, como apontamos acima, elas vêm galgando relevância social desde o final dos anos 1980, quando o quase consenso em torno do papel central do Estado na organização da economia, e mesmo da sociedade, deu lugar a um quase consenso mundial contrário (Harvey, 1992, 2008). Diante disso, interessa-nos perscrutar como são urdidos os elementos dessa legitimidade no Brasil contemporâneo, concebido nesse texto como localização específica de dinâmicas globais.

\section{Aproximações sinuosas com o Mercado e o Estado}

A legitimidade dos institutos e fundações empresariais precisa passar pelo distanciamento do mercado, ou seja, pelo fato de que eles não são empresas, e que são "sem fins lucrativos". Afinal, um grande banco ou uma fa- 
mília rica não podem assumir sem mediações a posição de artífices sociais só por possuírem capital econômico concentrado. Diante disso, para institutos empresariais, justamente por se vincularem objetivamente a grandes empresas, o esforço discursivo de distanciamento do reino econômico precisa ser constante. Ao mesmo tempo, esse distanciamento não pode ser completo por duas razões. Primeiramente, como o grupo todo tem a ganhar institucionalmente com a atuação do braço sem fim lucrativo, o vínculo entre os dois braços precisa ser claro, para que as empresas possam se beneficiar da imagem projetada pelo seu instituto ou sua fundação. Além disso, parte da legitimidade do instituto radica no fato de que se trata de uma instituição que conta com a experiência em gestão empresarial. Sobre isso, Heydemann e Toepler (2007) apontam que a recente integração entre os padrões de atuação de mercado e das instituições sem fins lucrativos faz com que o mercado seja cada vez mais determinante nas formas como os cidadãos percebem as fundações privadas.

No momento em que o mercado é estabelecido como a norma para a atuação, tanto do Estado quanto das instituições sem fins lucrativos, a aproximação e o distanciamento do Instituto com relação ao conjunto de empresas do grupo Itaú Unibanco ocorrerão de forma sinuosa. O material de divulgação lançado no aniversário de 26 anos da instituição, em 2013, pode ser útil para entendermos como se dá a construção discursiva das relações entre o braço cultural sem fins lucrativos e o grupo de empresas que o batiza. Na brochura sobre "posicionamento" da publicação, o superintendente administrativo da instituição afirma que "O Itaú Cultural é um modelo de gestão cultural, uma vez que, desde sua concepção, é uma instituição totalmente autônoma e independente, capaz de promover transformações significativas na relação da sociedade com a arte e a cultura brasileira". Na parte sobre "governança corporativa", afiança-se que

\begin{abstract}
Desde sua criação, o instituto conta com missão, visão e equipe próprias. A relação com o Grupo Itaú Unibanco, que financia as atividades, é marcada pela autonomia na gestão. A crença no potencial da instituição ao contribuir para a arte e a cultura do país orienta a definição de diretrizes estratégicas e a execução dos planos de ação, sem interferência das estruturas de marketing da holding. Na base de toda a atuação está uma sólida estrutura de governança, na qual se promovem princípios como transparência, equidade, prestação de contas e responsabilidade corporativa, objetivando a perenidade da instituição. A experiência empresarial do grupo serve como referencial e impulsiona a adoção das melhores práticas de gestão, de rígidos sistemas de controle e de acompanhamento contínuo pela administração. ${ }^{15}$
\end{abstract}

O trecho expõe a composição discursiva estabelecida para, ao mesmo tempo, aproximar-se e afastar-se do universo corporativo. A relação com a empresa traria conotação positiva na medida em que garantiria as melhores práticas corporativas, implicando boas práticas de gestão, eficiência, controle, etc. No entanto, há a preocupação em destacar a autonomia, em distanciar a atuação do Instituto das "estruturas de marketing da empresa". Composição difícil, tanto mais que, na parte de "Relacionamento" da série de publicações afirma-se que:

Auditorias de imagem realizadas anualmente, mês a mês, pelo Itaú Unibanco, comprovam que o Itaú Cultural é a empresa do grupo que mais gera visibilidade positiva em todas as mídias para o banco. Isso reforça o papel da instituição no fortalecimento da marca do conglomerado, que vê no instituto uma forma de contribuir para a evolução da sociedade (destaque nosso). ${ }^{16}$

Esse excerto também é elucidativo acerca da costura discursiva ziguezagueante que se busca realizar para banhar o bebê e manter limpa a água do banho. Ao mesmo tempo em que se afirma que o Instituto é uma empresa do grupo com papel no fortalecimento da marca do conglomerado, afirma-se que o instituto é visto como uma

${ }^{15}$ Itaú Cultural. Posicionamento. In: Relatório de atividades 2013.

${ }^{16}$ Itaú Cultural. Relacionamento. In: Relatório de atividades 2013. 
"forma de contribuir para a sociedade".

A busca por gerar "visibilidade positiva" não é infundada. Segundo o relatório anual para acionistas da Holding, o lucro líquido de janeiro a dezembro de 2013, mesmo ano da publicação acima, foi de $\mathrm{R} \$ 15,7$ bilhões, que corresponde a $20,7 \%$ de lucro com relação ao patrimônio líquido médio, ${ }^{17}$ tendo sido o maior da história dos bancos no Brasil até então. No mesmo momento, surgiam reivindicações trabalhistas contra os procedimentos do banco, que, de acordo com a Confederação Nacional dos Trabalhadores do Ramo Financeiro, teria reduzido em mais de $8 \%$ seu quadro funcional nos anos anteriores e "no primeiro trimestre de 2013, cortou mais 708 vagas". ${ }^{18}$ Também os procedimentos corporativos do próprio Itaú Cultural, dos quais seus gestores parecem bastante orgulhosos, a tomar pelos fragmentos discursivos acima, são alvos de frequentes críticas, especialmente, entre seus "colaboradores" individuais contratados reiteradamente como Pessoas Jurídicas prestadoras de serviços. ${ }^{19}$

Essa composição, que busca aproximarse e distanciar-se da imagem do mercado, é típica do dito terceiro setor, na atual conjuntura. Quando os níveis de concentração de capital e de desigualdade de renda batem recordes e as empresas adotam práticas administrativas - desfavoráveis aos trabalhadores, é mister seస्. parar-se delas. No entanto, elas são o modelo ๙ de governança e eficiência, de modo que é estratégico emulá-las. Além disso, no senso co-

خ 17 Disponível em: https://www.itau.com.br/_arquivosestaticos/ 5ิ RI/pdf/en/ENDCC31122013.pdf?title=Complete\%20Financial\%20Statements\%20-\%204Q13. Acesso em: 06/10/2015.

18 Disponível em: http://www.contrafcut.org.br/noticias/ campeao-de-demissoes-itau-e-o-banco-que-lidera-reclamacoes-no-procon-123c. Acesso em: 06/10/2015.

${ }^{19}$ Informações recolhidas em entrevistas realizadas pela autora com "prestadores de serviços" de institutos culturais sem fins lucrativos ligados a empresas, inclusive do Itaú Cultural. como bom prestador de serviços e agente pretensamente "técnico", seria superior ao Estado e à política, mesmo quando se trata da esfera dos direitos, como no caso dos direitos culturais, que, então, serão concebidos como serviços a serem prestados pelo agente mais apto a fazê-lo.

$\mathrm{E}$, no entanto, o posicionamento das instituições sem fins lucrativos com relação ao Estado não pode ser terminante, sobretudo no caso brasileiro e de outras sociedades nas quais o Estado historicamente é agente forte. A legitimidade da atuação dos institutos empresariais privados se faz, portanto, em uma composição sinuosa também com o poder público. Tal legitimidade se calca na finalidade pública que tais instituições professam e na destinação dos recursos de que podem dispor. Como se trata de entidades que contam com isenções fiscais, sua razão de ser se fundamenta no fato de possuírem utilidade pública. No caso de sociedades com forte presença estatal, a aproximação com entes públicos, que garante uma espécie de chancela estatal, faz com que a atuação pública das organizações sem fins lucrativos se legitime como tal. Isso não procede para todas as sociedades nem para todo tipo de organização sem fins lucrativos, mas, no caso das que são corporativas, a aproximação com pautas oficialmente públicas tende a trazer ganhos de legitimidade. É digno de nota o fato de que o Instituto Itaú Cultural conta, desde o início, com as boas vindas do Estado, tendo sido declarado de Utilidade Pública já em 1992. Portanto, o Itaú Cultural vem à luz em uma complexa composição com o Estado, em um momento em que a "sociedade civil" era chamada a compor a recém-redemocratizada república. Donde se explica o estabelecimento de movimentos simultâneos de aproximação e de diferenciação do poder público.

O terceiro artigo do estatuto de fundação da instituição dá a ver com nitidez esse posicionamento, em que nem distanciamento nem aproximação são inequívocos. Ao mesmo tempo em que afirma que uma das missões da instituição consiste no "desenvolvimento de atividades culturais que busquem a participa- 
ção e a inclusão cultural e social de todos os cidadãos, notadamente através de atividades junto a instituições públicas”, o artigo estatui, algumas linhas abaixo, que "o Instituto não terá atuação política, classista ou religiosa”. Embora negue a atuação política, o objetivo de atuar publicamente é nítido desde o princípio. Outra evidência disso é dada pelo presidente do grupo fundador e mantenedor da instituição, que já postulava o afastamento "Do tipo mais comum de mecenato, caracterizado pelo patrocínio de eventos independentes e de realização sem continuidade, para abraçar o lançamento e a manutenção de programas próprios com objetivos culturais de longo prazo" (Olavo Egydio Setúbal, apud Silva, 2000, p. 10). Ironicamente, os programas de longo prazo seriam financiados pelo "mecenato" fomentado pela Lei Rouanet.

As palavras da gerente de um dos principais programas da instituição, o Observatório Itaú Cultural, são elucidativas de como as relações entre a entidade e o poder público são concebidas. Para ela, o Itaú Cultural é criado no "momento de oficialização da cultura, sob os auspícios da Lei Sarney, representando um modelo de gestão".

Nesse modelo, a iniciativa privada, utilizando a renúncia fiscal, estabelece o seu projeto cultural e cria um corpo de profissionais diversos, fixo e próprio, voltado à pesquisa e à divulgação tecnológica de atividades e produtos. No aspecto da gestão cultural, os setores públicos e privados iniciam praticamente juntos uma nova forma de atuação. E, nos primeiros tempos, vão trocando experiências e influências tanto das formas de administração quanto de políticas e de produção. Embora a criação da Lei Rouanet (1991), em comparação com a lei anterior, tenha dado a possibilidade de o Estado interferir mais nas decisões de financiamento, por meio de um de seus mecanismos (FNC), percebe-se que é o setor privado ou o chamado "mercado" que constituirá um perfil do campo cultural e de seus agentes (Silva, 2012, p.183).

A "gestão cultural”, em tempos neoliberais, seria fruto de trocas e influências entre "setores públicos e privados", mas admite-se que o mercado teria assumido proeminência na definição do "perfil do campo cultural".
Esse trecho, de teor crítico, é enunciado em contexto restrito. Os materiais produzidos para ter divulgação mais ampla também apontam as "parcerias", "trocas" e "divisão de responsabilidades” entre o Itaú Cultural e os órgãos públicos de diversas esferas, mas as implicações disso para o desenho do que tem sido a "gestão da cultura” no país não são apontadas.

A publicação comemorativa dos 26 anos da Instituição é esclarecedora também a respeito das relações entre o instituto empresarial e o Estado, por trazer, sintomaticamente, uma seção específica sobre o "Relacionamento com o poder público", na qual se pode ler:

O diálogo com instituições parceiras em diversas esferas é altamente enriquecedor para o instituto e para a produção cultural brasileira. Um exemplo é a troca de informação e conhecimento com o Ministério da Cultura (MinC) como forma de dividir com o governo a responsabilidade de fomentar a produção, a disseminação e a sistematização da cultura em várias instâncias. Membro ativo dos núcleos de discussão do ministério, o Itaú Cultural faz parte do grupo de instituições que buscam soluções para o desenvolvimento de políticas públicas e o aperfeiçoamento de práticas já estabelecidas (grifos nossos).

O trecho acima explicita a presença ativa, no MinC, do Itaú Cultural, que se lança a influenciar, de maneira direta, as políticas públicas no país, por meio da presença nos espaços destinados à "participação da sociedade civil" em conselhos e instâncias consultivas, bem como por meio dos convênios que estabelece com o poder público.

O Observatório Itaú Cultural, por ter foco declarado "na gestão, na economia e nas políticas culturais", também é elucidativo das relações entre atuação pública e privada que analisamos. O material comemorativo dos 26 anos da instituição afirma, sobre o programa criado em 2006, que "O próprio Ministério da Cultura (MinC) inspirou-se nos conhecimentos sistematizados pelo Itaú Cultural para a criação do Observatório Brasileiro de Economia Criativa (Obec), vinculado à Secretaria de Economia Criativa, do MinC". ${ }^{20}$ Os zigueza${ }^{20}$ Itaú Cultural. Posicionamento. In: Relatório de ativida- 
gues com as instâncias públicas podem ser vislumbrados nos convênios com o Ministério da Cultura, como o projeto de "Formação de Gestores", "firmado com a Secretaria de Fomento e Incentivo à Cultura (Sefic) para a realização de cursos de capacitação para gestores culturais", lembrando que é nessa secretaria que são operados os mecanismos de incentivo à cultura. $\mathrm{O}$ Observatório, instância que "desenvolve ações de formação de gestores culturais", oferece pós-graduação a profissionais já atuantes no Brasil e organiza uma "semana de gestão cultural”, "em parceria com instituições locais (estaduais ou municipais), públicas e/ou privadas, cujo intuito é promover a discussão de temas contemporâneos da cultura e o intercâmbio de professores, pesquisadores e gestores culturais de todas as regiões do Brasil". Ademais, "por meio de oficinas e cursos on-line" e "em parceria com outras instituições, como o MinC e o Sesi", o programa dedicar-se-ia "à instrumentalização e à prática do agente cultural público ou privado" (Silva, 2012, p. 182).

Além disso, é bom lembrar que o Instituto Itaú Cultural tem seu plano de atividades custeado pelos recursos que atravessam o MinC anualmente, de modo que o próprio website da instituição privada se explicita como "realização" conjunta do Itaú Cultural com - a Lei de Incentivo à Cultura, o Ministério da จึ Cultura e o Governo Federal, inclusive com os ¿ respectivos logotipos emparelhados. ${ }^{21}$

A proximidade não se dá apenas com o nível federal da administração pública, pois a instituição tem convênios com Estados e prefeituras. Outro aspecto digno de nota são as redes estabelecidas por agentes atuantes tanto no ente privado quanto em órgãos públicos. Toiे memos um exemplo de cada um dos níveis da administração pública para termos uma ideia de como rodopiam as portas giratórias. A gerente do departamento jurídico do Itaú Cultural é integrante da Comissão Nacional de Incentivo à des 2013.

${ }^{21}$ Disponível em: http://www.itaucultural.org.br/. Acesso em: 24/10/2015.
Cultura (Cnic) do MinC. A atual presidente da Fundação de Cultura do Estado do Acre é também uma das curadoras do programa Rumos do Itaú Cultural, assim como o atual diretor do Centro Cultural São Paulo (CCSP) da Secretaria Municipal de Cultura de São Paulo. ${ }^{22}$

A gestão do Auditório Ibirapuera, na cidade de São Paulo, é um dos exemplos mais visíveis de como a instituição tem atuado publicamente. De 2005, quando foi inaugurado, a 2011, o Auditório foi gerido pelo Instituto Auditório Ibirapuera, uma organização da sociedade civil de interesse público (OSCIP). Em 2011, a Secretaria Municipal de Cultura de São Paulo passou à administração do auditório ao Itaú Cultural. O comunicado oficial da prefeitura explica que, embora o único proponente a ter respondido ao chamamento público tenha sido o próprio Itaú Cultural, os membros da comissão julgadora decidiram por não fazer uma segunda chamada em razão "da solidez da proposta apresentada” pela instituição. O comunicado aponta ainda que "Entre os itens destacados da proposta estão a manutenção da política cultural que vinha sendo desenvolvida, ampliação das atividades e investimentos de recursos próprios, sem recorrer a leis de incentivo". E acrescenta, ao final, que "O secretário municipal de Cultura, Carlos Augusto Calil, que homologou o resultado da seleção, ficou particularmente sensibilizado com a proposta de investimento exclusivo de recursos próprios, sem renúncia fiscal, algo extraordinário no panorama nacional". ${ }^{23}$

O episódio expressa e reforça a legitimidade com que a instituição conta frente a órgãos públicos. Pierre Bourdieu (1983, p.123) nos dá algumas pistas para pensar a questão, ao apontar que existe uma "razão social que

${ }^{22}$ Informações disponíveis em: https://rumositaucultural. org.br/comissao. Acesso em 26/10/2015. Um estudo detalhado sobre as redes estabelecidas por agentes atuantes tanto no ente privado quanto em órgãos públicos seria interessante para a compreensão das redes de influências entre as instâncias.

23 Disponível em: http://www.prefeitura.sp.gov.br/cidade/secretarias/cultura/noticias/?p=9290. Acesso em: $10 / 11 / 2015$. 
se legitima apresentando-se como razão puramente técnica" na "luta pelo monopólio da competência”. O autor afirma, ao analisar um campo social específico, que a autoridade de determinado agente "é definida como capacidade técnica e competência, compreendida como capacidade de falar e agir legitimamente", ou seja, "de maneira autorizada e com autoridade”. Assim, a autoridade não se define "naturalmente" pela competência técnica, mas é socialmente outorgada e, nesse sentido, ela depende do acúmulo de capital simbólico.

O caso acima deixa claro ainda que, em face dos "hibridismos público-privados constituídos por redes de elites, grandes corporações e órgãos públicos”, com a cessão da governança pública a agentes privados, o Estado pode tornar-se dependente da "expertise tecnocrática” desses atores e, diante disso, tampouco haveria espaço para deliberações democráticas de outras instâncias da sociedade (Raco, 2014).

A "parceria” na gestão do Auditório Ibirapuera, reveladora das formas pelas quais o Instituto Itaú Cultural tem galgado funções públicas, ${ }^{24}$ patenteia também que os desvios se tornaram a regra no país: as leis de incentivo à cultura têm por objetivo e justificativa o aumento do aporte de recursos privados para a área e, no entanto, o caso em que a instituição privada pretende atuar da forma prevista se torna declaradamente "extraordinário".

Os casos escolhidos são, na verdade, exemplos reveladores de um universo maior. Trata-se de um modelo, estatuído e condicionado pelo próprio Estado, que permite que grandes empresas, além de propagandearem a si mesmas com recursos públicos, assumam a posição de exercer poder sobre rumos públicos da cultura no país. A literatura sobre o tema aponta ainda que as relações que as fundações estabelecem com o poder público podem se dar em termos de complementaridade, confrontação e substituição (Mendes, 1999; Young, 2012). O que pudemos perceber, na análise

${ }^{24}$ Para mais detalhes, acessar http://www.auditorioibirapuera. com.br/ das relações entre Itaú Cultural e órgãos públicos de diversos níveis, é que elas são multifacetadas a ponto de incluir as modalidades acima apontadas pela bibliografia e outras.

A aproximação com o Estado e com o mercado é seletiva. No caso do Estado, não se fala de substituição ou confrontação, mas de trocas, intercâmbios, parcerias, divisão de responsabilidades, colaboração entre agentes públicos e privados, pois essa será uma das vias pelas quais os institutos empresariais buscarão garantir sua legitimidade diante da sociedade e também diante do próprio Estado, que, afinal, é a instância que condiciona sua existência em termos formais ou legais e, no caso do Brasil, também sua atuação em termos econômicos. No caso do mercado, os institutos buscam se apresentar como eficientes e pragmáticos ao prestarem determinados serviços, tal como o mundo corporativo, mas, ao mesmo tempo, se afastam dele, alegando independência e autonomia. A postura sinalizada é técnica, desideologizada, afeita à eficiência do mercado em um momento em que o próprio Estado é instado a agir nesses termos (Dardot; Laval, 2010; Swyngedouw, 2010). Assim, o mesmo movimento que aponta para a aproximação com entes públicos marca a diferença com relação a eles. Busca-se fazer uma mescla entre os aspectos positivos atribuídos ao mercado e ao Estado, livrando-se das representações negativas dos dois âmbitos. Os ganhos institucionais, simbólicos e econômicos para os institutos e para os grupos empresariais aos quais se ligam são evidentes. Há, entretanto, algo mais que nos importa salientar.

\section{CONSIDERAÇÕES FINAIS: a definição privada do bem público ou as vias si- nuosas de uma legitimação impossível}

Nas sociedades que se pretendem democráticas, a distribuição do poder precisa ser legítima. Nelas, é previsto também que o Estado não seja a única instância de exercício do poder. Diferentes forças sociais podem e 
devem tomar parte na composição dos rumos coletivos da sociedade. Essas forças não são consensuais, tampouco equivalentes. $\mathrm{O}$ reino político é a esfera do conflito, da tensão, da disputa. O mundo contemporâneo assiste, entretanto, manifestações do que tem sido chamado de pós-política. Wilson e Swyngedouw (2014) apontam que a pós-política rejeita divisões ideológicas e dissensos em nome de uma lógica que concebe a organização social em termos de administração, de gestão pragmática das questões públicas a partir de uma razão técnica. A concepção da sociedade como algo coletivo, como entidade política composta por cidadãos e grupos em disputa passa ao largo dessa visão de mundo.

Muito tem sido dito acerca das possibilidades positivas de atuação conjunta entre Estado e sociedade civil. Especialmente quando se trata de temas globais, como direitos humanos e meio ambiente, o Estado-nação já não teria alcance suficiente e, diante disso, estaria em curso um processo de multiplicação e fragmentação dos regimes de governança (Biermann; Pattber; Van Asselt, 2009; Ruggie 2004; Sassen, 2007; Waddell; Khagram, 2007). Mas uma coisa é dizer que a sociedade civil deve se autodeterminar e que público não coincide com estatal. Outra coisa é imaginar que forças ๑ de mercado, que concentram capital econômi-
O ideal seria minorar a política em favor da técnica. Contudo, embora não diga seu nome, esse discurso é, ele mesmo, político. Ele vê a sociedade como uma agremiação de indivíduos racionais cujas necessidades individuais precisam ser racionalmente atendidas. Esse átomo que comporia a sociedade é concebido como um indivíduo consumidor de serviços, como um cliente (Fontenelle, 2015; Streeck, 2013). Esse "discurso forte", que "deriva seu poder social do poder político e econômico daqueles cujos interesses expressa", apresenta normativamente o mundo que pretensamente apenas descreve (Bourdieu, 1998). Nele, a discussão sobre a legitimidade do poder não tem lugar, porque a sociedade não é admitida como lócus de disputas de poder, mas concebida como objeto a ser gerido por uma boa governança, por sua vez definida como um conjunto de operações pragmáticas na solução de problemas, para os quais é preciso oferecer respostas objetivas, neutras e isentas.

Não é necessário adentrar nas discussões e querelas específicas da teoria política pós-fundacional ao empregar a categoria pós-política para designar o processo no qual os bens públicos ou comuns passam a ser geridos privadamente, como não se tratasse de uma operação política (Swyngedouw, 2010; Wilson; Swyngedouw, 2014). No caso específico que temos em tela, vemos grandes empresas, especialmente do setor financeiro, arbitrando o destino de recursos públicos em uma área que é constitucionalmente um direito no país e que, de maneira geral, trata-se de um bem público. Algumas fazem isso de maneira direta, patrocinam musicais da Broadway e exibem seus logotipos. Outras criam instituições sem fins lucrativos, destinadas a atuar publicamente de maneira sistemática, criando uma mediação que transforma concentração de capital econômico em um poder político que não diz seu nome. Buscando assumir uma posição nem pública, nem privada, supostamente neutra no que tange a ideologias e interesses, elas se colocam como vozes da pós-política no Brasil contemporâneo. 
Tal como os autores que fundam essa discussão, lançamos mão dessa noção para problematizá-la, pois, quando grandes grupos financeiros, com ou sem o intermédio de instituições sem fins lucrativos, assumem a dianteira do fomento à cultura no país, estamos em face não de uma configuração pós-política, mas de um tipo específico de política que beneficia uns em detrimento de outros, como costuma ocorrer com a política. Diante disso, convém lembrar que o Estado não é uma instância pública isenta a arbitrar, de fora, forças sociais em disputa. Ele é sempre privatizado. A questão é a favor de quem. Ele existe em relação com várias instâncias sociais, que buscam operacionalizar as capacidades estatais para seus respectivos desígnios. Essas forças sociais não são equivalentes e, na conjuntura neoliberal, as forças de mercado, especialmente financeiras, teriam adquirido ainda mais proeminência nessa disputa.

Quando o exercício do poder político fica de tal maneira amarrado ao capital econômico e, mais que isso, à resolução supostamente técnica das questões públicas, é patente que não estamos diante de uma configuração democrática da distribuição e do exercício do poder. Tamanha concentração de capital econômico, político e simbólico só pode ocorrer se ela for permitida e condicionada por instâncias políticas, de maneira que faz sentido, para os detentores de capital, aproximar-se de tais instâncias para delas dispor.

Mais nuançado que isso, entretanto, é o processo de tornar-se uma instância pública por estar putativamente além da política, nas altas instâncias da técnica e da eficiência, ou seja, por meio da deslegitimação da própria política. Da maneira como isso está consolidado no Brasil contemporâneo, em um cenário de crise econômica como o que o país atualmente atravessa, com bancos cada vez mais lucrativos e com o Estado em situação de ajuste fiscal e redução de arrecadação, o fomento à cultura fica cada vez mais dependente da atuação de grandes grupos empresariais do setor fi- nanceiro. E os rumos da cultura cada vez mais dependentes da atuação pública de institutos empresariais privados sobre bens públicos.

Esse é um fenômeno importante, mas circunscrito. Exageramos epistemologicamente seu valor para dar a ver um processo social mais amplo. No limite, está em curso uma disputa simbólica pelo arbítrio dos bens públicos ou comuns. Ela se dá mundialmente, e o caso que analisamos pode ser visto como uma localização desse processo global (Sassen, 2007). Como destaca Prewitt (2006), embora sem levantar essa questão mais ampla, as fundações possuem um poder enorme de estabelecer a agenda pública e de manipular incentivos a seu favor. E acrescenta que os privilégios de que se beneficiam são outorgados em razão do bem público que promovem. No entanto, ele aponta a circularidade dessa formulação, pois o que emerge desse processo como o bem público é resultado de uma deliberação privada. Nosso objeto põe às claras que estamos diante de tentativas de se implementar uma visão privada do que é o bem público e, mais que isso, de fazê-lo passando ao largo da discussão necessariamente política sobre a natureza do que é ou deveria ser o bem público. Para darmos mais um giro no argumento, trata-se de abolir a própria ideia de que o bem público deve ser objeto de discussão. A pós-política busca transformar em desnecessária uma legitimação impossível.

Diante disso, levantar a questão, sempre premente, da legitimidade dos agentes que atuam publicamente significa fazer uma indagação sobre o caráter mesmo da democracia (Swyngedouw, 2011). É preciso que nos perguntemos o que fundamenta a legitimidade de instituições (e famílias) ligadas a grandes empresas que têm assumido a posição de agentes públicos, tanto mais porque, a partir do poder simbólico que elas adquirem ao atuar como tal, elas concorrem para a deslegitimação da própria política. David Harvey (2008) afirma que o neoliberalismo significou a restauração do poder de classe ao redor do mundo. No Brasil, o neoliberalismo adquire cores próprias. 
Por aqui, não havia um poder a ser restaurado, porque ele não havia sido deposto. Mas as relações entre capital privado e poder político assumem, hoje, novas nuances. O desenvolvimento de institutos e fundações empresariais é uma delas. A esfera da cultura é uma das mais implicadas nessa transformação, de maneira que a agenda da sociologia da cultura, no país, precisa contemplar esse agente. Para além dos campos de saber específicos e da esfera da cultura em particular, manter esse objeto anfíbio no foco das preocupações acadêmicas é prolífico para a compreensão das relações de poder entre Estado, mercado e sociedade no mundo contemporâneo.

Recebido para publicação em 21 de abril de 2016 Aceito em 05 de maio de 2016

\section{REFERÊNCIAS}

ALVES, M. A. O conceito de sociedade civil: em busca de uma repolitização. Organização e Sociedade, v. 11, Edição especial, 2004.

ANHEIER, H. K.; LEAT, D. Philanthropic foundations: what rationales? Social research: an international quarterly, [S.1], v. 80, n. 2, p. 449-472, Summer 2013.

AUGUSTIN, A. C. O neoliberalismo e seu impacto na política cultural brasileira. [S.1]: Fundação Casa de Rui Barbosa, S/d.

BIERMANN, F; PATTBERG, P.; VAN ASSELT, H. The fragmentation of global governance architectures: a framework for analysis. Global Environmental Politics, [S.l], v. 9, n. 4, p. 14-40, Nov. 2009.

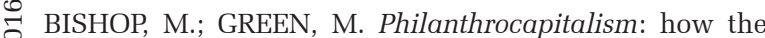
rich can save the world and why we should let them. ง London: A. \& C. Black, 2008. L.; Le nouvel esprit du \& capitalisme. Paris: Gallimard, 1999.

ஓं BOURDIEU, P. As regras da arte. São Paulo: Companhia if das Letras, 1996.

$\infty$ pour servir à la résistance contre l'invasion néo-liberale. $\stackrel{\infty}{\wedge}$ Paris: Liber, 1998. के $\overline{2000}$.

Les structures sociales de l'économie. Paris: Seuil,

$>$ $\overline{1989}$.

O poder simbólico. Rio de Janeiro: Bertrand Brasil,

. O campo científico. In: ORTIZ, R (Org.). Sociologia. São Paulo: Ática, 1983.

BRESSER PEREIRA, L. C. A reforma do Estado dos anos 90: lógica e mecanismos de controle. Lua Nova, [S.l], n. 45, 1998.

CASTEL, R. Metamorfoses da questão social: uma crônica do salário. Petrópolis, RJ: Vozes, 1998.
DARDOT, P.; LAVAL, C. La nouvelle raison du monde. Essai sur la société neoliberale. Paris: La Découverte, 2010.

EAGLETON, T. A idéia de cultura. São Paulo: Editora UNESP, 2005.

FONTENELLE, I. Alcances e limites da crítica no contexto da cultura política do consumo: movimentos brasileiros de contestação e mercantilização da resistência. Estud. av., São Paulo, v. 30, jan./abril de 2016. No prelo.

Organisations as producers of consumers. Organization, [S.1], v. 22, n. 5, p. 644-660, Sept. 2015.

FOUCAULT, M. História da sexualidade $I$ : a vontade de saber. Rio de Janeiro: Graal, 1985.

GIFE. Censo GIFE 2011- 2012. São Paulo: GIFE, 2013.

GOMBRICH, E. H. A história da arte. Rio de Janeiro: LCT, 2012.

GRAMSCI, A. O Conceito de Hegemonia em Gramsci. Rio de Janeiro: Graal, 1991.

HEYDEMANN, S.; TOEPLER, S. Foundations and the challenge of legitimacy in comparative perspective. 2007. In: PREWITT, K. et al. The legitimacy of philanthropic foundations: United States and European perspectives. New York: Russel Sage Foundation, 2006.

HARVEY, D. Condição pós-moderna. São Paulo: Loyola, 1992.

. Neoliberalismo: história e implicações. São Paulo: Loyola, 2008.

HAMMACK, D. C. American debates on the legitimacy of foundations.2007. In: PREWITT, K. et al. The legitimacy of philanthropic foundations: United States and European Perspectives. New York: Russel Sage Foundation, 2006.

HILGERS, M. The historicity of the neoliberal state. Social Anthropology, [S.1], v. 20, n. 1, p. 80-94, 2012.

IBGE. As fundações privadas e associações sem fins lucrativos no Brasil 2010. n. 20, 2012.

JAMESON, F. Pós-Modernismo: a lógica social do capitalismo tardio. 2 ed. São Paulo: Ática, 2004.

ITAÚ CULTURAL. Relatório de Atividades 2013. 2013.

LANDIM, L. O "setor" sem fins lucrativos no Brasil. História, tendências e debates recentes. In: LANDIM, L. Para além do mercado e do Estado? Filantropia e cidadania no Brasil. Rio de Janeiro: Cadernos do ISER, 1993.

The nonprofit sector in Brazil. In: SALAMON, L. M.; ANHEIER, H. K. The nonprofit sector in the developing world: a comparative analysis. Manchester, UK: Manchester University Press, 1998.

LA PRADELLE, M. Les vendredis de Carpentras: faire son marché, en provence ou ailleurs.Paris: Fayard, 1996.

MARX, K.; ENGELS, F. A ideologia alemã. São Paulo: Martins Fontes, 2001.

MEDEIROS, A. K.; ALVES, M. A.; FARAH, M. F. S. Programa cultura viva e o campo organizacional da cultura: análise de políticas públicas pela perspectiva institucionalista. Rev. Adm. Pública, Rio de Janeiro, v. 49, n. 5, p. 1215-1235, set./out. 2015.

MENDES, L. C. A. Estado e terceiro setor: uma análise de duas iniciativas de aproximação. Anpad, Foz do Iguaçu, v. 23, 1999. Disponível em: http://anpad.org.br. Acesso em: 15 jan. 2008.

MICHETTI, M. Coletivos e redes culturais no Brasil contemporâneo: notas sobre as relações entre cultura, economia e política na conjuntura neoliberal. [S.l.: s.n]. Capítulo de livro no prelo.

O discurso da diversidade no universo corporativo: 
"institutos" empresariais de cultura e a conversão de capital econômico em poder político. Contemporâneas, [S.1], No prelo.

NOBRE, M. Imobilismo em movimento. São Paulo: Companhia das Letras, 2013.

NOGUEIRA, F. A.; SCHOMMER, P. C. Quinze anos de investimento social privado no Brasil: conceito e práticas em construção. São Paulo: ANPAS/ENANPAD, 2009.

OLIVIERI, C. G. Cultura neoliberal: leis de incentivo como política pública de cultura. São Paulo: Editora Escrituras, 2004. (Edição Digital).

ORTIZ, R. Anotações sobre o universal e a diversidade. Rev. bras. educ., Belo Horizonte, v. 12, n. 34, p. 7-16, 2007.

Universalismo/Diversidade: contradiçóes da modernidade-mundo. São Paulo: Boitempo, 2015.

PECK, J. Zombie neoliberalism and the ambidextrous state. Theoretical Criminology, [S.1], v. 14, p. 104-110, 2010.

POLANYI, K. A Grande transformação - as origens de nossa época. Rio de Janeiro: Campus, 1980.

PONTE, E. Por uma cultura pública: organizações sociais, oscips e a gestão pública não estatal na área da cultura. São Paulo: Itaú Cultural, 2012. 208 p.

PREWITT, K. American foundations: what justifies their unique privileges and powers. In: PREWITT, K. et al. The Legitimacy of philanthropic foundations: United States and European perspectives. New York: Russel Sage Foundation, 2006.

RACO, M. The post-politics of sustainability planning: privatisation and the demise of democratic government. In: WILSON, J.; SWYNGEDOUW. E. (Eds.). The Post-Political and Its Discontents: Spaces of Depoliticization, Spectres of Radical Politics. Edinburgh: Edinburgh University Press, 2014.

REIS, A. C. F. Marketing cultural e financiamento do cultura: teoria e prática em um estudo inter-nacional comparado. São Paulo: Pioneira Thomson Learning, 2003.

ROELOFS, J. Foundations and public policy: the mask of pluralism. New York: Suny Press, 2003.

RUGGIE, J. G. Reconstituting the global public domain Issues, Actors and Practices. Eur. I. Int. Relat.,[S.1], v. 10, n. 4, p. 499-531, 2004.

RUBIN, A. A. C.; BARBALHO, A.; CALABRE, L. (Orgs.) Políticas culturais no governo Dilma. Salvador: EDUFBA, 2015. $281 \mathrm{p}$

RUBIN, A. A. C. Políticas culturais do governo Lula. Revista Lusófona de Estudos Culturais. v. 1, n.1, p. 224242,2013

SALLUM JUNIOR, B. O Brasil sob Cardoso: neoliberalismo e desenvolvimentismo. Tempo Social Rev. Social. USP, São Paulo, v. 11, n. 2, p. 23-47, out. 1999.

SARKOVAS, Y. O incentivo fiscal à cultura no Brasil. Teoria e Debate. Edicão 62. Maio 2005. In: SASSEN, S. A Sociology of Globalization. New York: Norton \& Company, 2007.

SASSEN, S. Anotações de aula. Global Governance Regimes Seminar. Columbia University. SeptemberDecember 2015.

SINGER, A. Os sentidos do Lulismo. Reforma gradual e pacto conservador. São Paulo: Companhia das Letras, 2012.

SILVA, L.S. O público e o privado: a política cultural brasileira nos casos dos Institutos Moreira Salles e Itaú Cultural. 2000. Dissertação (Mestrado) - Universidade de São Paulo, São Paulo, 2000.

SILVA, S. C. Ações de Formação do Observatório Itaú
Cultural para Gestores de Cultura: Desafios de Motivação e Continuidade In: CALABRE, L.(Org.). Políticas culturais: pesquisa e formação. São Paulo: Itaú Cultural; Rio de Janeiro : Fundação Casa de Rui Barbosa, 2012. 332 p.

SOUZA, J. et al. A ralé brasileira. Quem é e como vive. Belo Horizonte: Editora UFMG, 2009.

STEINER, C. B. African Art in Transit. Cambridge: Cambridge University Press, 1994

STREECK, W. O cidadão como consumidor. Consideraç̃es sobre a invasão da política pelo mercado. Revista Piauí, Teresina, v. 79, abr. 2013.

SWYNGEDOUW. E. Apocalypse forever? Post-political populism and the spectre of climate change. Theor. Cult. Soc., London, v. 27, n. 2-3, p. 213-232, 2010.

Governance innovation and the citizen: the janus face of governance beyond-the-state. Urban Studies, [S.l], v. 42 , n. 11, p. 191-206, 2005.

Interrogating post-democratization: reclaiming egalitarian political spaces. Political Geography, [S.l], v. 30, n. 7, p. 370-380, 2011.

WACQUANT, L. Three steps to a historical anthropology of actually existing neoliberalism. Social Anthropology,[S.l], v. 20, n. 1, p. 66-79, 2012.

WADDELL, S.; KHAGRAM, S. Multi-stakeholder global networks: emerging systems for the global common good; In: GLASBERGEN, F.; BIERMANN.; MOL, A. P. J. Partnerships, governance and sustainable development: reflections on theory and practice. Cheltenham Glos, UK: Edward ElgarPublishing, 2007. p 261-287.

WARNKE, M. O artista da corte: os antecedentes dos artistas modernos. São Paulo: Edusp, 2001.

WEBER, M. Economia e sociedade: fundamentos da sociologia compreensiva. Brasília: Editora da Universidade de Brasília, 2012. v. 1.

Metodologia das ciências sociais. São Paulo: Cortez; Campinas: Editora da Unicamp, 1996. v.2.

WILSON, J. The Jouissance of Philanthrocapitalism: Enjoyment as a post-political factor. In: WILSON, J.; SWYNGEDOUW, E. (Eds.). The post-political and its discontents: spaces of depoliticization, spectres of radical politics. Edinburgh: Edinburgh University Press, 2014.

WILSON, J.; SWYNGEDOUW. E. (Eds.). The Post-political and its discontents: spaces of depoliticization, spectres of radical politics. Edinburgh: Edinburgh University Press, 2014.

WU, C. Privatização da cultura: a intervenção corporativa na arte desde os anos 1980. São Paulo: Boitempo, 2006.

YOUNG, D. R. Complementary, Supplementary, or Adversarial? Nonprofit - Government Relations. In: BORIS, E. T.; STEUERLE, C. E. (Eds.). Nonprofits and government: collaboration and conflict. 2. ed. Washington: Urban Institute Press, 2012. 


\section{THE PRIVATE DEFINITION OF THE PUBLIC GOOD: the acting of business institutes in the cultural sphere}

\section{Miqueli Michetti}

This article analyzes the public action of private business institutes in the cultural sphere in contemporary Brazil. Such action is conditioned by the Brazilian public power through incentive laws to culture by tax waiver. The main goal of this text is to search how private foundations and institutes place themselves as one of the mediators that permit the conversion of economic capital in political power, or also in a pretense post-politic governance. The research methodology of this article was constituted of a literature review and of the qualitative and quantitative data analysis of the use of public resources resulting from tax waiver. The sociological discourse analysis also grounds the study. In conclusion, this article points out a reopening of the debate about the legitimacy of private agents acting in the public sphere, which makes us question the nature of democracy itself

KEYwORDS: Cultural institutes. Incentive laws to culture. Contemporary Brazil. Post-politics.Legitimacy.
LA DEFINITION PRIVEE DU BIEN PUBLIC: l'action des institutions d'affaires dans le domaine de la culture

Miqueli Michetti

L'article fait l'analyse de l'action publique des institutions d'affaires privées dans le domaine de la culture au sein du Brésil contemporain. Une telle action est conditionnée par les pouvoirs publics nationaux par l'intermédiaire de lois destinées à encourager la culture grâce à des allègements fiscaux. L'objectif essentiel de ce texte est de scruter comment les fondations et les institutions privées s'imposent comme l'une des médiations qui permet de convertir le capital économique en pouvoir politique, ou encore, en gouvernance prétendue post-politique. La méthodologie de la recherche qui a permis l'élaboration de cet article a consisté à revoir les bibliographies à ce sujet et à analyser les données qualitatives et quantitatives concernant l'utilisation des ressources publiques provenant des allègements fiscaux. L'analyse sociologique du discours a également été utilisée pour fonder cette étude. En conclusion, l'article recommande la ré-ouverture du débat concernant la légitimité des acteurs privés qui agissent dans le domaine publique, ou encore de mener une enquête sur le caractère lui-même de la démocratie.

Mots-CLÉs: Institutions culturelles. Lois d'encouragement à la culture. Brésil contemporain. Post-politique. Légitimité.

Miqueli Michetti - Doutora em Sociologia pela Unicamp. Pós-doutorado na Columbia University of New York. Professora do Departamento de Fundamentos Sociais e Jurídicos da EAESP-FGV. Integra o Grupo de Estudos e Pesquisa sobre Práticas Culturais Contemporâneas (GEPRACC), desenvolvendo pesquisas nas áreas de sociologia da cultura e sociologia econômica. Tem experiência na área de Sociologia, com ênfase em Sociologia Contemporânea, Sociologia da Cultura, Sociologia Econômica e Sociologia da Globalização, atuando principalmente nos seguintes temas: mercados de bens simbólicos, "economia da cultura", "indústrias criativas”, políticas culturais, e atuação pública de instituições privadas sem fins lucrativos. Publicações recentes: Moda brasileira e mudialização. São Paulo: Annablume/Fapesp, 2015; Por que a moda brasileira quer ser global? Desigualdade das trocas simbólicas mundiais e ethos dos atores da moda nacional. Sociologia \& Antropologia, v. 05, p. 515-532, 2015; Modas do mundo e moda mundial: sobre a partilha desigual de tarefas simbólicas entre Norte Global e Sul Global no mercado mundial de moda ética?. Arquivos do CMD, v. 2, p. 1, 2014; Do caldeirão de culturas ao buffet de diversidade cultural: os usos das -brasilidades- como discurso na moda contemporânea. Revista Ciências Sociais Unisinos, v. 50, p. 25-33, 2014. 